\title{
Effect of Nitrogen, Phosphorus and Potassium Level on Floral Characteristics of Chrysanthemum (Chrysanthemum morifolium Ramat) cv. Bidhan Madhuri
}

\author{
Subrat Kumar Senapati*, Tushar Kanti Das and Geeta Pandey \\ Department of Floriculture \& Landscaping, College of Agriculture, Orissa University of \\ Agriculture and Technology, Bhubaneswar-751003, Odisha, India \\ *Corresponding author
}

Keywords

Chrysanthemum, Bud, Floral attributes, Diameter

Article Info

Accepted:

22 June 2020

Available Online:

10 July 2020

\section{A B S T R A C T}

The present investigation entitled Effect of nutrient management in chrysanthemum (Chrysanthemum morifolium Ramat cv. BidhanMadhuri) was carried out at BTCC, OUAT, Bhubaneswar during winter 2017-18. The experiment consists of eleven treatments having different combinations of Nitrogen $(\mathrm{N})$, Phosphorous $(\mathrm{P})$ and Potassium $(\mathrm{K})$ fertilizers $(\mathrm{kg} / \mathrm{ha})$ which was replicated thrice in RBD experimental design. Among all the treatment, $\mathrm{T}_{10}$ having a fertilizer combinations of $\mathrm{N}=120, \mathrm{P}=125, \mathrm{~K}=140 \mathrm{~kg} / \mathrm{ha}$ i.e. the optimum dose of fertilizer higher than that of the RDF found to be effective in producing luxuriant floral attributes i.e. minimum days taken for flower bud appearance $(48.267$ days),minimum days taken for flower bud opening (61.4days), maximum flower diameter $(5.847 \mathrm{~cm})$, dry $(1.173 \mathrm{~g})$ and high fresh weights of flower( $3.256 \mathrm{~g})$, number of flowers(67.733), flowering duration (74.333days) and vase life period.(20.000days).Hence it can be recommended for obtaining optimum growth, desired flowering and yield attributes and this treatment having fertilizer combinations of $\mathrm{N}=120, \mathrm{P}=125, \mathrm{~K}=140 \mathrm{~kg} / \mathrm{ha}$ is suggested for Chrysanthemum crop in Bhubaneswar condition.

\section{Introduction}

Chrysanthemum is one of the most important flowering plant, commercially grown in different parts of the world. It is a native of northern hemisphere mainly Europe and Asia. It belongs to family Asteraceae and is commonly called as the "Queen of the East". Flowers symbolize purity, peace, love, beauty and passion. It was first cultivated in China and then spread to Japan. Hence, Chrysanthemum became the floral emblem of the imperial family of Japan and subsequently regarded as the National flower of Japan. 
Chrysanthemum is one of the most popular flowers grown in our country for its diversified beauty of colours, shapes, shades and keeping quality. It is highly suitable for beds, pots and for floral arrangement. In India, chrysanthemum is very popular as loose flower, cut flower as well as pot plant also. Chrysanthemum is mostly used in our country for making garlands, veni, bracelets and in flower decoration and religious offerings. On account of its good keeping quality, flowers can be transported to a distant market easily. In India, chrysanthemum occupies a place of pride, both as commercial flower crop and as a popular exhibition flower. Chrysanthemums are divided into two basic groups, garden hardy mums and exhibition type. The exhibition varieties can be used to create many amazing plant forms, such as large disbudded blooms, spray forms, and many artistically trained forms, such as thousand-bloom standard (trees), fans, hanging baskets, topiary, bonsai and cascades.

Though many factors influence successful production of chrysanthemum just like soil fertility, irrigation, plant density, plant protection measures, etc. but manurial schedule plays a major role in crop production. In modern days soil health is degraded due to many factors that is why crops grown in such soil without fertilization usually suffer from nutrient deficiency and the application of fertilizers becomes an essential tool to boost up the yield.

Improper nutrition leading towards nutrient imbalance in plant is a major factor contributing to low yield of flower. Under normal Agro-climatic conditions, the deficiency of major nutrients viz., $\mathrm{N}, \mathrm{P}$ and $\mathrm{K}$ is common and causes serious problems in flower production. Hence, this research has been taken to study the different floral characteristics of Chrysanthemum under different doses of $\mathrm{N}, \mathrm{P}$ and $\mathrm{K}$.

\section{Materials and Methods}

A field experiment entitled "Effect of nutrient management in chrysanthemum (Chrysanthemum morifolium Ramat) cv. Bidhan Madhuri was conducted at Biotechnology-cum-tissue culture center (BTCC) of O.U.A.T, Bhubaneswar. The terminal herbaceous cuttings of 4-5 cm length were taken from the healthy mother plants of cultivar BidhanMaduri by giving a cut just below a node with a sharp knife. After preparing the cuttings, they were inserted up to two third of its length in to fine sand medium. The healthy one month old rooted cuttings were transplanted in polythene bags consisting of soil. The well sprouted, rooted and healthy cuttings were uplifted from nursery beds and carefully transplanted in each plot at the spacing of $30 \times 30 \mathrm{~cm}$ with a density of 16 plants per plot having net plot size $1.3 \mathrm{mx} 1.3 \mathrm{~m}$ after 45 days in month of November. The experiment comprised of eleven (11) treatments replicated thrice and was laid out in a Randomized block design. Each treatment was composed of 16 plants and standard recommended packages of practices were followed in each treatment. Pinching was done in 15 days interval in each treatment. Fertilization was done according to treatment. Nitrogen was applied in two splits i.e. half at planting and rest half at 30 DAP. All Potassium and Phosphorus in all treatments were applied as basal. Numbers of days were counted from the date of transplanting to first flower bud initiation in randomly selected five plants and average was computed for each treatment to determine number of days taken for appearance of flower buds in each treatment. To determine numbers of days taken for first flower bud opening, days were counted from the date of transplanting to first flower opening in randomly selected five plants and average was computed for each treatment. Other data just like diameter of flowers, weight of the 
flowers, and length of the flower stalk, floral duration and vase life were observed from five randomly selected flowers from each plot at full bloom stage. The data obtained were averaged and computed.

\section{Results and Discussion}

The earliest days taken for flower bud appearance was 48.267 days and earliest days taken for flower bud opening was 61.4 days obtained in treatment $\mathrm{T}_{10}$ having fertilizer combination of $\mathrm{N}=120 \mathrm{~kg} / \mathrm{ha}, \mathrm{P}=125 \mathrm{~kg} / \mathrm{ha}$, $\mathrm{K}=140 \mathrm{~kg} /$ ha which was significantly superior over the rest treatments. This might be due to the reason that with optimum doses of NPK application, nutrient uptake efficiency of the plants also got increased and consequently, plants could put up requisite vegetative in lesser time due to which the flowering was advanced as compared to the recommended practices and other treatments where lower doses of NPK were applied.

These results are in conformity with the findings of Kumar (2001) in Chrysanthemum, Kumar and Rana (2003) in Carnation cv. Chaubad Yellow, Acharya et al., (2004) and Ravindra et al., (2018) in African marigold. This may be also due to optimum availability of nutrients which are necessary for the synthesis of protein and cytokinin consequently affects the cell division. Accumulation of carbohydrates coupled with a relatively lesser vegetative growth rate and promotes translocation of phytohormones to the shoots which probably induce early flower bud differentiation and eventual initiation of flowering. Such results are in agreements with findings of Ramesh et al., (2002), Naggar (2009), Madhuri and Barad (2018) in Carnation.

The data recorded on flower diameter influenced by nutrient management revealed that maximum flower diameter $(5.847 \mathrm{~cm})$ was obtained in treatment number $\mathrm{T}_{10}$ having fertilizer combination of $\mathrm{N}=120, \mathrm{P}=125$, $\mathrm{K}=140 \mathrm{~kg} / \mathrm{ha}$ followed by treatment $\mathrm{T}_{9}$ $(5.667 \mathrm{~cm})$ having fertilizer combinations of $\mathrm{N}=120, \mathrm{P}=125, \mathrm{~K}=120 \mathrm{~kg} / \mathrm{ha}$ which were significantly superior than other treatments. Maximum flower diameter has been observed in treatment number $T_{10}$ due to adequate application of nutrients particularly Nitrogen which might have stimulated cell elongation, which would have been resulted to an increase in diameter of flower. However, minimum flower diameter i.e. $4.313 \mathrm{~cm}$ was found in control $\left(\mathrm{T}_{11}\right)$ treatment having fertilizer combinations of $\mathrm{N}=0, \mathrm{P}=0, \mathrm{~K}=0$ $\mathrm{kg} / \mathrm{ha}$.As the higher nitrogen level might have accelerated the photosynthetic activities by increasing the source size (number of branches and leaf area) thereby developing flowers with more photosynthates, which might have resulted in increased cell division and cell expansion of flower tissues that enhanced the flower size in term of flower diameter. The results are in agreement with findings of Singh and Sangama (2000), Kumar et al., (2002) in Chrysanthemum, Singh et al., (2004) in Gladiolus. Actually application of Nitrogen and Potassium at higher levels accelerated the photosynthetic activities by increasing the source size (number of branches and leaf area) and persistence of more number of green leaves for a longer period of time which helped in accumulation of more photo assimilates and increased turgor potential in plant tissue there by allowing the entry of more water in to the cells there by regulated the cell expansion in the floral tissue ultimately leading to an increase in the flower size in terms of flower diameter. Such kinds of results were obtained in Agrawal et al., (2002), Kishore et al., (2010) and Pal and Ghosh (2010) in African Marigold and Ravi et al., (2017) in Chrysanthemum. Maximum fresh weight (3.256g) and dry weight (1.766g) were obtained in treatment $T_{10}$. This result may be 
also due to the role of nitrogen as abundant supply of Nitrogen at higher level might have improved vegetative growth of plant which accelerated the photosynthetic activities of plants and caused more storage of carbohydrates resulting improved flower weights. This may be due to the reason that nitrogen application enhances metabolic process and results in increase flower weight. The results were obtained by Chauhan (2012) in golden rod and Ahirwar et al., (2012) in African marigold.

Maximum flowering duration (74.333days) was obtained in treatment T10having fertilizer combination of $\mathrm{N}=120, \mathrm{P}=125, \mathrm{~K}=140 \mathrm{~kg} / \mathrm{ha}$ followed by treatment $\mathrm{T}_{4}(72.200)$ having fertilizer combinations of $\mathrm{N}=80, \mathrm{P}=125$, $\mathrm{K}=140 \mathrm{~kg} / \mathrm{ha}$ which were significantly higher than all other treatments. However, minimum flowering duration (59.400) was obtained in control treatment $\left(\mathrm{T}_{11}\right)$ where no fertilizer was applied.

This might be due to increased vegetative growth of plants at higher nitrogen level that might have enhanced turgidity of flowers by increasing the rate of photosynthesis and other metabolic activities which in turn might have increased flowering span in annual chrysanthemum. These results are in line with the findings of Gaikwad et al., (2004) in China aster. Mainly, Nitrogen was found most effective in extending the flowering duration and the result was close conformity with Muktanjali et al., (2004) in marigold, Jauhari et al., (2005) in gladiolus.

Maximum vase life period i.e. 20 days was obtained in treatment T10 having fertilizer combination of $\mathrm{N}=120, \mathrm{P}=125, \mathrm{~K}=140 \mathrm{~kg} / \mathrm{ha}$. This improvement in vase life period due to the Nitrogen which produces carbohydrates that extend the vase life but within increase in Nitrogen, depletion of carbohydrates causing digestion of proteins which might reduce sugar content, an important factor to extend vase life in Chrysanthemum as stated by Disha (2016) in Bird of paradise and Patel and Chaudhari (2011) in Chrysanthemum. Vase life of flower enhanced with nitrogen application as nitrogen is a very important constituent of nucleic acid, protoplasm and it might have increased carbohydrate synthesis, amino acids etc. from which phytohormones like auxins, cytokinin, giberellins have been synthesized resulting in enhancing the vase life and flower quality. These results are close conformity with those of Sonawane et al., (2009), Kishore et al., (2010) in gladiolus, Dhaked et al., (2013) in Calendula and Somendra et al., (2018) in snap dragon.

Maximum length of pedicel i.e. $14.443 \mathrm{~cm}$ was obtained in treatment $\mathrm{T}_{10}$ having fertilizer combination of $\mathrm{N}=120, \mathrm{P}=125, \mathrm{~K}=140 \mathrm{~kg} / \mathrm{ha}$. The increase in length of flower stem may be attributed to excessive growth on radial aspect of plant as observed through increase in plant height with higher nutrient application.

The enhanced pedicel length is due to higher level application of Nitrogen that causes improvement in plant metabolism i.e. higher amino acid production, chlorophyll formation at faster rate, transformation of carbohydrates, and translocation of phytohormones more quickly and efficiently. Minimum length of pedicel $(11.250 \mathrm{~cm})$ was obtained in $\mathrm{T}_{11}$ due to zero application. These results are in agreement with findings of Patel and Chaudhari (2011) in Chrysanthemum, Gaikwad et al., (2004) in China aster and Disha (2016) in Bird of paradise, Ranjan et al., (2019) in Chrysanthemum.

Maximum number of flowers per plant were obtained in treatment $\mathrm{T}_{10}$ having fertilizer combinations of $\mathrm{N}=120, \mathrm{P}=125, \mathrm{~K}=140 \mathrm{~kg} / \mathrm{ha}$ which is influenced by the nutrients Nitrogen and Potassium. 
Table.1 Effect of different levels of Nutrients on different flowering attributes

\begin{tabular}{|c|c|c|c|c|c|c|c|c|c|}
\hline Treatments & $\begin{array}{l}\text { Number of } \\
\text { days taken for } \\
\text { flower bud } \\
\text { appearance }\end{array}$ & $\begin{array}{l}\text { Number of } \\
\text { days taken } \\
\text { for flower } \\
\text { bud opening }\end{array}$ & $\begin{array}{l}\text { Flower } \\
\text { diameter } \\
(\mathrm{cm})\end{array}$ & $\begin{array}{c}\text { Fresh } \\
\text { weight } \\
\text { (gm) }\end{array}$ & $\begin{array}{c}\text { Dry } \\
\text { weight } \\
\text { (gm) }\end{array}$ & $\begin{array}{c}\text { Duration } \\
\text { of } \\
\text { flowering }\end{array}$ & $\begin{array}{l}\text { Vase } \\
\text { life }\end{array}$ & $\begin{array}{l}\text { Pedicel } \\
\text { length } \\
(\mathrm{cm})\end{array}$ & $\begin{array}{c}\text { Number of } \\
\text { flowers } \\
\text { per plant }\end{array}$ \\
\hline $\begin{array}{l}\text { T1 } \\
(\mathrm{N}=100, \mathrm{P}=125, \mathrm{~K}=125)\end{array}$ & 53.267 & 67.866 & 4.987 & 2.875 & 0.960 & 66.733 & 16.667 & 13.197 & 58.367 \\
\hline $\begin{array}{l}\mathrm{T} 2 \\
(\mathrm{~N}=80, \mathrm{P}=125, \mathrm{~K}=100)\end{array}$ & 56.933 & 72.6 & 4.580 & 2.578 & 0.700 & 63.933 & 17.335 & 12.690 & 48.267 \\
\hline $\begin{array}{l}T 3 \\
(N=80, P=125, K=120)\end{array}$ & 56.600 & 72.266 & 4.633 & 2.735 & 0.853 & 68.267 & 17.667 & 12.973 & 56.067 \\
\hline $\begin{array}{l}\mathrm{T} 4 \\
(\mathrm{~N}=80, \mathrm{P}=125, \mathrm{~K}=140)\end{array}$ & 56.267 & 70.866 & 4.740 & 3.016 & 1.003 & 72.200 & 19.667 & 12.583 & 62.400 \\
\hline $\begin{array}{l}\text { T5 } \\
(\mathrm{N}=100, \mathrm{P}=125, \mathrm{~K}=100)\end{array}$ & 52.467 & 67.533 & 4.913 & 2.548 & 0.683 & 62.467 & 16.000 & 13.647 & 45.600 \\
\hline $\begin{array}{l}\text { T6 } \\
(N=100, P=125, K=120)\end{array}$ & 52.200 & 66.866 & 5.180 & 2.695 & 0.733 & 65.933 & 17.667 & 14.067 & 55.133 \\
\hline $\begin{array}{l}\text { T7 } \\
(N=100, P=125, K=140)\end{array}$ & 51.733 & 66 & 5.233 & 3.052 & 1.163 & 71.000 & 19.333 & 14.213 & 64.867 \\
\hline $\begin{array}{l}\text { T8 } \\
(N=120, P=125, K=100)\end{array}$ & 51.133 & 65.733 & 5.500 & 2.568 & 0.727 & 64.867 & 16.667 & 13.833 & 50.400 \\
\hline $\begin{array}{l}\text { T9 } \\
(\mathrm{N}=120, \mathrm{P}=125, \mathrm{~K}=120)\end{array}$ & 50.333 & 64.6 & 5.667 & 2.733 & 0.780 & 68.800 & 18.000 & 14.737 & 57.367 \\
\hline $\begin{array}{l}\text { T10 } \\
(N=120, P=125, K=140)\end{array}$ & 48.267 & 61.4 & 5.847 & 3.256 & 1.173 & 74.333 & 20.000 & 14.443 & 67.733 \\
\hline $\begin{array}{l}\text { T11 } \\
(\mathrm{N}=0, \mathrm{P}=0, \mathrm{~K}=0)\end{array}$ & 58.933 & 77.666 & 4.313 & 1.766 & 0.627 & 59.400 & 14.333 & 11.250 & 42.000 \\
\hline $\mathrm{SE}(\mathrm{m}) \pm$ & 0.358 & 0.711 & 0.104 & 0.053 & 0.038 & 0.827 & 0.052 & 0.052 & 1.534 \\
\hline C.D. at $5 \%$ & 1.064 & 2.113 & 0.308 & 0.159 & 0.113 & 2.136 & 0.154 & 0.154 & 4.556 \\
\hline
\end{tabular}

Where, T1, T2, T3...T11 indicates the number of treatments. 
Interaction had showed a significant influence on number of flowers per plant as in one hand, Nitrogen played a vital role in diverting food reserves to the site of flower bud differentiation which resulted in more number of flowers per plant and this might be due to the fact that applied Nitrogen has significantly increased growth parameters like number of branches, which might have synthesized more metabolites and ultimately led to increased flower production which findings are closed conformity with Chawla et al., (2007), Patel and Chaudhari (2011), Satur et al., (2012) and Joshi et al., (2013) in Chrysanthemum. The yield of flowers per plant increased with the application of nitrogen mainly because of increased carbohydrate reserve for the development of floral primordial apart from the structural development of the plant. The present results were in the confirmation with the earlier findings of Agrawal et al., (2002), Rajbeer and Jitendra (2009) in African marigold and Ravi et al., (2017) in Chrysanthemum. On the other hand, Potassium also involved in acceleration of many enzymatic reactions which led to the more number of flowers per plant. Minimum number of flowers per plant (67.733) was obtained in control treatment $\left(\mathrm{T}_{11}\right)$ due to the zero level application of Nitrogen and Potassium. The results are in agreement with findings of Dorajeeraoet.al.(2012).

In conclusion, the results revealed that treatment $\mathrm{T}_{10}$ having a fertilizer combination $\mathrm{N}=120, \mathrm{P}=125, \mathrm{~K}=140 \mathrm{~kg} / \mathrm{ha}$ was found to be more effective in increasing flowering attributes such as number of days taken for flower bud appearance, number of days taken for flower bud opening, flower diameter, number of flowers per plant, flower weight per plant, length of pedicel, duration of flowering and vase life period of flowers. So, it can be concluded that the optimum dose of fertilizer higher than the RDF T1( $N=100$ $\mathrm{P}=125 \mathrm{~K}=125 \mathrm{~kg} / \mathrm{ha}$ ) where Phosphorus remains constant has resulted in incorporating a sound and luxuriant vegetative growth subsequently increasing the flower yield in Chrysanthemum in Bhubaneswar.

\section{References}

Agarwal, S., Agarwal, N., Dixit, A. and Yadav, R.N. 2002. Effect of $\mathrm{N}$ and $\mathrm{K}_{2} \mathrm{O}$ on African marigold in Chhattisgarh region. J. Orn. Hort., 5(1): 86-87.

Ahirwar, M.K., Ahirwar, K. and Megha, Sukla. 2012. Effect of plant densities, nitrogen and phosphorus levels on growth, yield and quality of African marigold. Ann. Pl. Soil Pes., 14(2):153155.

Arora, J.S., 2012. Introductory Ornamental Horticulture. Kalyani Publisher Pvt. Ltd., West Bengal.

Chawhan, A.P. 2012. Effect of nitrogen and phosphorus on growth, quality and flower production of golden rod (Solidagocandensis L.) cv. Local. M.Sc. Thesis submitted to Navsari Agricultural University, Navsari.

Chawla, S.L., Mohammed, S., Mahawer, L.N and Jain, M.C. 2007. Effect of nitrogen and phosphorus on vegetative growth and flower yield of Chrysanthemum (Chrysanthemum morifolium) cv. Nilima. Ann. Agric. Res., 28(1): 25-28.

Dhaked, R., Chand, S. and Srivastava, R. 2013. Effect of spacing and levels of nitrogen on growth, flowering and yield of calendula (Calendula officinalis), Pantnagar Journal, 11(3): 365-368.

Disha, P. 2016.Effect of nitrogen and phosphorus on growth, flowering and yield of bird of paradise (Strelitzia reginae) under 50 per cent shade net house. M.Sc. Thesis submitted to Navsari Agricultural University, Navsari.

Dorajeerao, A. V. D., Mokashi, A. N., Patil, V. S., Venugopal, C. K., Lingaraju, S. 
and Koti, R. V. 2012. Effect of graded levels of nitrogen and phosphorus on growth and yield of garland Chrysanthemum (Chrysanthemum coronarium L.), Karnataka J. Agric. Sci., 25(2): 224-228.

Gaikwad, S. A., Patil, D. S. S. and Patil G. D. 2004.Effect of different levels of nitrogen and phosphorus on the growth and flower production of China aster (Callistephus chinensis (L). Nees). J. Maharashtra Agric. Univ. 29(2): 140142.

Jauhari, S., Srivastava, R. and Srivastava, P. C. 2005. Effect of Zinc on growth, flowering, corm attributes, post-harvest life, leaf and corm nutrients status in gladiolus cv. Red Beauty. Prog. Hort., 37(2): 423-428.

Joshi, N.S., Varu, D.K., Barad, A.V. and Pathak, D.M. 2013. Performance of varieties and chemical fertilizers on growth and flowering in chrysanthemum. Intl. J Agric Sci.;9(1):182-188.

Kishore, G.R., Arya, J.K. and Ghalot, P.K.2010.Effect of different levels of nitrogen, phosphorus and potassium on growth and flowering of African marigold cv. Pusa Narangi Gainda. Progressive Agriculture. 82(6): 941-45.

Kumar, J. and Rana, P. 2003. Response of nitrogen and IAA in spray carnation. Journal of Ornamental Horticulture, New series. 6(3): 285-286.

Kumar, J., Chauhan, S.S. and Singh, P.V. (2002). Responses of $\mathrm{N}$ and $\mathrm{P}$ fertilization on China aster. Paper presented in National Symposium on Indian Floriculture in the New Millennium, 25-27 Feb, Bangalore, PP. 38.

Kumar, P. 2001. Effect of nitrogen and phosphorous application under flood and drip irrigation on growth, yield and quality of Chrysanthemum
(Dendranthema grandiflora). Ph.D. Thesis submitted to Dr Y. S. Parmar University of Horticulture and Forestry, Nauni, Solan, Himachal Pradesh.

Madhuri G and Barad A V. Flowering parameters of carnation (Dianthus caryophyllus L.) varieties under protected condition influenced by NPK nutrients through foliar spray. The Pharma Innovation Journal 2018; 7(7): 105-108.

Madhuri, G. and Barad, A. V. 2018. Flowering parameters of carnation (Dianthus caryophyllus L.) varieties under protected condition influenced by NPK nutrients through foliar spray. The Pharma Inn. J. 7(7): 105-108

Muktanjali, J., Paithankar, D. H., Warade, A. D.and Anjali, T. P. 2004. Effect of nitrogen and phosphorus on China aster. Adv. Pl. Sci. 17(1): 163-165.

Naggar, A. H. E. 2009. Response of carnation (Dianthus caryophyllus L.) plants to foliar nutrition. World J Agric. Sci. 5(5): 622-630.

Pal, P., and Ghosh, P. 2010. Effect of different sources and levels of potassium on growth, flowering and yield of African marigold (Tagetes erecta Linn.) cv. 'Siracole'. Indian $J$. Nat. Prod. Res., 1(3): 371-75.

Patel, N.K. and Chaudhari, S.R. 2011. Influence of nitrogen on quality parameters of different varieties of chrysanthemum. Asian Sci., 6(1,2):6365.

Rajbeer, J.S., and Jitendra, K. 2009. Effect of nitrogen and pinching on growth and flowering in African marigold cv. Pusa Narangi Gainda. Ann. Hort. 2(2): 22627.

Ramesh, K., Singh, K., Reddy, B. S. 2002. Effect of planting time, photoperiod $\mathrm{GA}_{3}$ and pinching on carnation. J. Orn. Hort. 5(2): 20-23.

Ranjan, K., Bhatt, D.S., Chawla, S. L., Bhatt, 
S.T., Priya, S.S. 2019. Effect of Nitrogen and Phosphorus on Growth, Flowering and Yield of Cut Chrysanthemum cv.Thai Chen Queen. Curr. Agri. Res. 7(3): 15-25.

Ravi Teja, P., Vijaya, B. and Subbaramamma, P. 2017. Influence of Graded Levels of Nitrogen and Potassium Combinations on the Flower Yield of Annual Chrysanthemum (Chrysanthemum coronarium L.). Int. J. Curr. Microbiol. App. Sci. 6(10): 1124-1134.

Ravindra, K., Ashok, K. and Abhinav, K. 2018. Effect of Nutrients on Growth, Flowering and Yield of African Marigold (Tagetes erecta L.) cv. Pusa Narangi Gainda. Int. J. Curr. Microbiol. App. Sci., 7(06): 205-209.

Satar, V.P., Panchbhai, D.M., Seema, T. and Sushma, S. 2012. Effect of nitrogen and phosphorus levels on flower yield and quality of annual chrysanthemum. Asian J Hort., 7(2): 343-346.

Singh, K. P. and Sangama.2000. Effect of graded level of $\mathrm{N}$ and pruning on China aster (Callistephus chinensis) cutivar Kamini, Indian J. Hort., 57(1): 87-89.

Sonawane, S.P.D., Dodke, D.J. and Dhane, S.B. 2009. Studies on $\mathrm{N}$ and $\mathrm{P}$ application with and without farmyard manure on the growth of plant, branches and flowering character of China aster, J. Maharashtra Agric. Univ., 34(1): 9091.

Verma, S., Kumar, A., Kumar, A. 2018.Effect of nitrogen, phosphorus and their interaction on flower quality and vase life of Snap dragon. Pl. Archives. 18(1): 62-64.

\section{How to cite this article:}

Subrat Kumar Senapati, Tushar Kanti Das and Geeta Pandey. 2020. Effect of Nitrogen, Phosphorus and Potassium Level on Floral Characteristics of Chrysanthemum (Chrysanthemum morifolium Ramat) cv. Bidhan Madhuri. Int.J.Curr.Microbiol.App.Sci. 9(07): 2594-2601. doi: https://doi.org/10.20546/ijcmas.2020.907.306 